\title{
Kandungan Fenolik, Flavonoid dan Aktivitas Antioksidan Ekstrak Daun Paku Laut (Acrostichum aureum L.) Fertil dan Steril
}

\author{
Naovi Nur Fadia Hanin, Rarastoeti Pratiwi*
}

Faculty of Biology, Universitas Gadjah Mada, Jl. Teknika Selatan, Sekip Utara, Yogyakarta, 55128

*Corresponding author, email: rarastp.ugm.ac.id

\section{ARTICLE INFO}

\section{Article history:}

Received 01/11/2017

Received in revised form 02/01/2018

Accepted 02/01/2018

\section{Keywords:}

antioxidant

flavonoid

phenolic compounds

spores

Acrostichum aureum L.

DOI: $10.22146 / j t b b .29819$

\begin{abstract}
A B S T R A C T
Sea Fern (Acrostichum aureum L.), which typically grows in mangrove ecosystem, has two distinguished leaves which are fertile leaves (rich in spores) and sterile leaves (no spores). Those leaves are known rich in phenolic compounds. Flavonoids, moreover, which belong to class of phenolic compound, have antioxidant activity. This study aims were to analyze the phenolic content, flavonoid content, and antioxidant activity of fertile leaves, sterile leaves, and spores of sea fern which grow in mangrove ecosystem that is located in Kulon Progo, Yogyakarta. Leaf and spore samples were extracted using ethanol solvent. Then, total content of phenol and flavonoid were measured by spectrophotometry, while the antioxidant activity was measured by DPPH method. The results showed that the phenolic content of fertilized leaves and sterile leaves did not show a significant difference. In other hand, the spores sample showed highest both of flavonoids content $(2.32 \mathrm{mg} / \mathrm{mL})$ and the antioxidant activity with the IC50 value was $23.25 \mathrm{ppm}$. Thus, the ethanolic extracts of spores of sea fern sterile leaves showed the highest flavonoid content and could be categorized as a very strong antioxidant.
\end{abstract}

\section{Pendahuluan}

Senyawa fenolik merupakan senyawa yang dihasilkan oleh tumbuhan sebagai respons terhadap stres lingkungan. Senyawa fenolik berfungsi sebagai pelindung terhadap sinar UV-B dan kematian sel untuk melindungi DNA dari dimerisasi dan kerusakan (Lai \& Lim, 2011). Komponen pada senyawa ini diketahui memiliki peranan penting sebagai agen pencegah dan pengobatan beberapa gangguan penyakit seperti arteriosklerosis, disfungsi otak, diabetes dan kanker (Garg et al, 2016).

Kelompok terbesar dari senyawa fenolik adalah flavonoid. Setiap tumbuhan umumnya mengandung satu atau lebih senyawa kelompok flavonoid dan memiliki komposisi kandungan flavonoid yang khas (Indrawati \& Razimin, 2013). Flavonoid terdapat hampir di semua bagian tumbuhan, seperti daun, akar, kulit tepung sari, nektar, bunga, buah dan biji (Neldaati et al., 2013). Senyawa flavonoid memiliki aktivitas antioksidan yang dapat meningkatkan pertahanan diri dari penyakit yang diinduksi oleh radikal bebas. Aktivitas antioksidan pada senyawa flavonoid diketahui memiliki potensi untuk mencegah terjadinya penumpukan lemak sehingga mampu mengatasi masalah obesitas yang menjadi penyebab penyakit DM (Anwar, et al., 2017). Selain itu senyawa flavonoid juga diketahui dapat mengurangi risiko terjadinya penyakit jantung dan kanker (Ukoha et al., 2011).

Paku Laut (Acrostichum aureum L.) adalah satusatunya tumbuhan paku dengan genus yang tumbuh di kawasan hutan mangrove. Tumbuhan ini tumbuh dengan baik di habitat air payau (Lobo \& Khrisnakumar, 2014). Paku Laut terdistribusi secara luas di seluruh di daerah tropis, di antaranya di negara Brazil, Ekuador, Paraguay, India, Sri Lanka, Bangladesh dan Indonesia (Raja \& Ravindranadh, 2014). Salah satu daerah dengan Paku Laut yang melimpah adalah kawasan hutan Mangrove, Kulon Progo Yogyakarta. Selama ini, pemanfaatan daun Paku Laut di daerah tersebut hanyalah sebagai pakan ternak. Di negara lain, daun Paku Laut telah dimanfaatkan secara tradisional untuk menghentikan pendarahan, penghilang rasa sakit dan 
mengobati cloudy urine pada wanita (Raja \& Ravindranadh, 2014). Kandungan glikosida, saponin, steroid dan fronds pada tanaman ini juga telah digunakan sebagai pain-killer dan mengobati penyakit perut (Hossain et al., 2011).

Beberapa penelitian yang telah dilakukan pada daun Paku Laut menunjukkan adanya aktivitas antioksidan dan jumlah total senyawa fenolik yang cukup tinggi. Lai dan Lim (2011) juga menyebutkan bahwa daun Paku Laut termasuk dalam tumbuhan paku yang mengandung senyawa fenolik dengan kadar antioksidan dan total fenolik sedang. Khan et al. (2013) menyebutkan bahwa kandungan antioksidan pada ekstrak etanol Acrostichum aureum mencapai 41,95 $\mu \mathrm{g} / \mathrm{mL}$.

Daun Paku Laut dibedakan menjadi dua macam, yaitu daun fertil dan daun steril. Daun fertil berwarna agak lebih cokelat dan pada bagian bawah dipenuhi sporangia (Ragavan et al., 2014). Dari penelitian yang telah dilaporkan sebelumnya, belum terdapat informasi mengenai aktivitas antioksidan dan kandungan total flavonoid pada daun Paku Laut yang fertil dan steril, serta pada spora Paku Laut.

Penelitian ini bertujuan untuk mengetahui kandungan golongan senyawa fenol, flavonoid dan aktivitas antioksidan daun Paku Laut fertil, daun steril, daun fertil yang diambil sporanya dan spora Paku Laut. Hasil penelitian ini diharapkan mampu memberikan informasi bagian daun yang memiliki akivitas antioksidan tertinggi dikaitkan dengan kandungan fenol dan flavanoid.

\section{Bahan dan Metode}

\subsection{Lokasi dan Waktu Penelitian}

Penelitian ini dilaksanakan pada bulan Agustus 2016 Februari 2017. Pengambilan sampel dilakukan di Hutan Mangrove Kulon Progo, Yogyakarta. Adapun tempat pelaksanaan penelitian yaitu di Laboratorium Penelitian dan Pengujian Terpadu (LPPT) Universitas Gadjah Mada Yogyakarta.

\subsection{Preparasi Sampel}

Sampel yang digunakan dalam penelitian ini adalah daun paku fertil, daun steril, spora yang dilepaskan dari daun fertil, dan daun fertil yang telah dilepas sporanya. Daun yang diambil merupakan daun yang berada di pucuk kedua hingga keempat pada batang Paku Laut. Daun yang digunakan pada penelitian ini telah di identifikasi oleh Laboratorium Sistematika Tumbuhan Fakultas Biologi Universitas Gadjah Mada dan dinyatakan sebagai daun Acrostichum aureum $L$. Sampel diekstrak dengan pelarut etanol, akuades, asam galat, pereaksi Folin-ciocalteu, sodium karbonat 20\%, quercetin, aluminium klorida $10 \%$, larutan DPPH dan kertas saring.
Daun Paku Laut fertil dan steril dikoleksi dan dibagi menjadi 4 sampel, yaitu daun fertil, daun steril, spora, dan daun fertil yang telah diambil sporanya. Khusus untuk spora Paku Laut, di preparasi dengan cara mengerok daun fertil. Selanjutnya sampel berupa daun dipotong kecil dan dikering anginkan selama 24 jam. Sampel dikeringkan menggunakan oven dengan suhu $60^{\circ} \mathrm{C}$. Daun yang telah kering dihaluskan dengan cara diblender atau di giling.

\subsection{Ekstraksi Senyawa Bioaktif}

Sampel diekstraksi menggunakan pelarut etanol 95\% selama 24 jam Ekstrak etanol disaring dengan kertas saring dan diuapkan pelarutnya menggunakan vacuum rotary evaporator sampai diperoleh ekstrak kental. Ekstrak kental yang diperoleh dari proses tersebut disimpan di dalam refrigerator dengan suhu $\pm 4^{\circ} \mathrm{C}$.

\subsection{Penghitungan Kadar Fenolik}

Sebanyak $50 \mathrm{mg}$ sampel ditimbang dan ditambahkan 0,5 $\mathrm{ml}$ pereaksi Folin-ciocalteu dan $4 \mathrm{ml}$ akuabides. Campuran dibiarkan Selama 10 menit pada suhu kamar dan ditambahkan 1,5 $\mathrm{ml}$ sodium karbonat $20 \%$. Larutan dipanaskan dalam waterbath suhu $40^{\circ} \mathrm{C}$ selama 20 menit dan di dinginkan. Selanjutnya ditambahkan akuabides hingga volume $10 \mathrm{ml}$. Larutan dipindahkan ke dalam kuvet dan dibaca serapannya menggunakan spektrofotometer pada panjang gelombang $755 \mathrm{~nm}$. (Chaovanalikit \& Wrolstad, 2004).

\subsection{Perhitungan Kadar Flavonoid}

Sampel ditimbang sebanyak $5 \mathrm{mg}$, lalu ditambahkan $0,3 \mathrm{ml}$ natrium nitrit $5 \%$. Setelah 5 menit tambahkan $0,6 \mathrm{ml}$ aluminium klorida $10 \%$. Setelah ditunggu selama 5 menit larutan ditambahkan natrium hidroksida $1 \mathrm{M}$ sebanyak $2 \mathrm{ml}$. selanjutnya ditambahkan akuades hingga $10 \mathrm{ml}$ pada labu takar. Larutan dipindahkan ke dalam kuvet dan dibaca serapannya menggunakan spektrofotometer dengan panjang gelombang $510 \mathrm{~nm}$ (Pekal \& Pyrzynska, 2014).

\subsection{Uji Aktivitas Antioksidan}

Ekstrak Paku Laut ditimbang sebanyak $10 \mathrm{mg}$, lalu dilarutkan dalam $10 \mathrm{~mL}$ methanol p.a $(1000 \mu \mathrm{g} / \mathrm{mL})$, larutan ini merupakan larutan induk. Sebanyak 500, 1000, 2000, 3000, dan $4000 \mu \mathrm{L}$ larutan induk dimasukkan ke dalam tabung reaksi $5 \mathrm{~mL}$ untuk mendapatkan konsentrasi 100, 200, 300, 400, dan $500 \mu \mathrm{g} / \mathrm{mL}$. Tiap tabung ditambahkan $1 \mathrm{~mL}$ DPPH dan metanol (p.a) hingga $5 \mathrm{~mL}$. Campuran dihomogenkan dan diinkubasi selama 30 menit. Kemudian 
absorbansi diukur dengan spektrofotometer dengan panjang gelombang $516 \mathrm{~nm}$.

\subsection{Perhitungan $I C_{50}$}

Presentase inhibisi dihitung menggunakan rumus berikut :

$$
\% \text { Inhibisi }=\frac{(\text { Serapan blanko }- \text { Serapan sampel })}{\text { Serapan blanko }} \times 100 \%
$$

Persen inhibisi adalah nilai penghambatan nilai radikal bebas. Sedangkan untuk menghitung konsentrasi antioksidan $(\mu \mathrm{g} /$ $\mathrm{mL}$ ) yang dibutuhkan untuk mereduksi DPPH sebanyak $50 \%$ digunakan perhitungan nilai $I_{50}$. Nilai $I_{50}$ diperoleh dari perpotongan garis antara sumbu konsentrasi dan sumbu hambatan, kemudian dimasukkan ke dalam persamaan $\mathrm{y}=\mathrm{a}$ $+\mathrm{bx}$, dengan $\mathrm{y}=50$ dan nilai $\mathrm{x}$ menunjukkan $\mathrm{IC}_{50}$. Ekstrak disebut aktif sebagai antioksidan jika nilai IC $C_{50}$ kurang dari 200 $\mu \mathrm{g} / \mathrm{mL}$ (Molyneux, 2004).

\section{Hasil dan Pembahasan}

Data yang didapat dari proses ekstraksi berupa fraksi dalam gram dan persentase rendemen. Hasil tersebut dapat dilihat pada Tabel 1.

Tabel 1. Hasil ekstraksi Acrostichum aureum

\begin{tabular}{lllll}
\hline No & Bahan & $\begin{array}{l}\text { Simplisia } \\
\text { (g) }\end{array}$ & $\begin{array}{l}\text { Fraksi Etanol } \\
\text { (g) }\end{array}$ & $\begin{array}{l}\text { Rendemen } \\
\text { (\%) }\end{array}$ \\
\hline 1. & Daun Steril & 200,02 & 21,89 & 10,94 \\
2. & Daun Fertil & 200,03 & 40,42 & 20,21 \\
3. & Spora & 200,02 & 23,88 & 11,94 \\
4. & $\begin{array}{l}\text { Daun diambil } \\
\end{array}$ & 200,02 & 21,80 & 10,9 \\
\hline
\end{tabular}

Berdasarkan Tabel 1, diketahui bahwa hasil ekstraksi terbanyak dihasilkan dari sampel daun fertil yang memiliki selisih hampir $18 \mathrm{~g}$ dari sampel lainnya. Hal tersebut menunjukkan bahwa pada sampel daun fertil mengandung banyak senyawa bioaktif yang bersifat polar, sesuai dengan sifat pelarutnya yaitu etanol. Pemilihan pelarut yang digunakan untuk ekstraksi harus tepat agar dapat menarik senyawa yang dikehendaki (Firdiyani et al., 2015). Pelarut akan lebih mudah menarik ekstrak dengan sifat kepolaran yang sama. (Sarastani et al., 2002). Etanol memiliki polaritas yang tinggi sehingga dapat mengekstrak senyawa yang bersifat polar, di antaranya senyawa fenolik, steroid, terpenoid, alkaloid dan glikosida (Dia et al., 2015). Etanol juga memiliki titik didih yang tinggi serta tidak beracun sehingga aman digunakan (Aziz, et al., 2014).

Selanjutnya dilakukan pengukuran kadar senyawa fenolik. Metode yang digunakan adalah metode FolinCiocalteau dengan asam galat sebagai pembanding. Hasil dari pengujian kadar fenolik dapat dilihat pada Gambar 1.

Berdasarkan analisis One-Way ANAVA yang telah dilakukan pada uji fenolik, tidak terlihat perbedaan yang signifikan pada keempat sampel. Hal tersebut dapat disebabkan karena daun yang digunakan pada penelitian ini adalah daun dewasa sehingga produksi metabolit sekunder yang berupa senyawa fenolik sama tingginya. Pendapat ini didukung oleh penelitian oleh Anwar et.al (2017) yang membandingkan kadar fenolik berdasarkan usia daun pada tanaman Aquilaria beccariana, disebutkan bahwa pada daun dewasa memiliki kemampuan yang lebih besar untuk mensintesis metabolit sekunder. Oleh karena itu kandungan fenolik dan flavonoid pada daun dewasa lebih tinggi. Metabolit sekunder disintesis seiring dengan pertambahan usia daun, namun pada daun yang tua jumlah sintesis metabolit sekunder akan semakin sedikit. Selain genetik, beberapa faktor yang mempengaruhi banyaknya sintesis fenolik adalah cahaya, suhu, kekeringan, dan salinitas (Harbone \& Williams, 2000).

Bagi tumbuhan di ekosistem Mangrove seperti Paku Laut, sinar matahari merupakan salah satu faktor stres lingkungan primer, sehingga menjadi penyebab tingginya kadar fenolik. Sinar matahari adalah sumber energi terbesar yang digunakan tumbuhan untuk aktivitas fotosintesis. Selain menghasilkan senyawa utama berupa metabolit primer yang mendukung pertumbuhan, proses fotosintesis juga menghasilkan senyawa metabolit sekunder dan produk samping berupa ROS (reactive oxygen species). ROS bersifat toksik dan berpotensi merusak komponen fotosintesis. Keberadaan ROS dapat direduksi dan dikontrol oleh senyawa

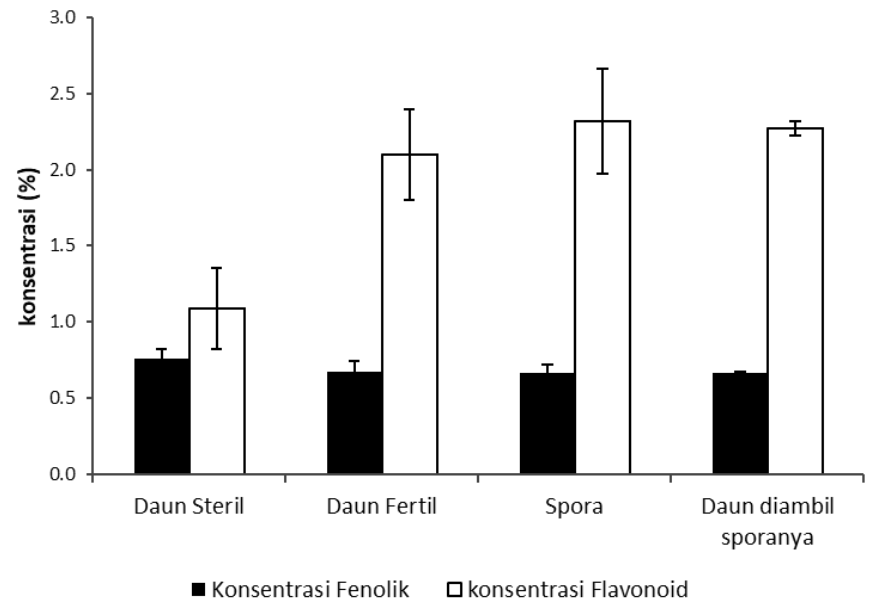

Gambar 1. Kadar fenolik dan flavonoid total daun dan spora tanaman Arostichum aureum L. 
yang memiliki aktivitas antioksidan dan enzim anti oksidatif. Aktivitas antioksidan dapat menjaga sel intraseluler mempertahankan kadar ROS pada level yang rendah (Shebis et al., 2013). Organ yang berperan penting dalam proses fotosintesis adalah daun, karena daun mengandung kloroplas yang berfungsi untuk menangkap sinar matahari. Rhodes dan Yemm (1965) menyebutkan bahwa jumlah kloroplas pada daun dipengaruhi oleh paparan cahaya yang terlalu lama. Kloroplas akan terdiferensiasi dan mengakumulasi lebih banyak protein, lemak, dan pigmen fotosintesis (Biswal et al., 2003). Paparan sinar matahari akan meningkatkan produksi metabolit sekunder, namun jika paparan sinar matahari terlalu berlebihan menyebabkan produksi metabolit sekunder menurun. (Ibrahim \& Jaafar, 2012). Penelitian yang dilakukan oleh Li dan Kubota (2009) menyebutkan penggunaan sinar LED sebagai pengganti sinar matahari dapat meningkatkan konsentrasi fenolik pada daun selada.

Sementara itu, hasil perhitungan kadar flavonoid pada Gambar 1, menunjukkan bahwa banyaknya senyawa flavonoid tidak selalu berbanding lurus dengan kadar total senyawa fenolik pada suatu sampel. Spora merupakan bagian dari tumbuhan yang dapat bertahan di lingkungan ekstrem. Bahkan spora dapat bertahan selama satu tahun di atas permukaan tanah (Forest Practice Branch Ministry of Forest, 2002). Hal tersebut disebabkan karena flavonoid adalah salah satu senyawa metabolit sekunder yang dapat melindungi kelangsungan hidup spora sehingga spora banyak mengandung senyawa flavonoid.

Selanjutnya dilakukan perhitungan aktivitas antioksidan menggunakan metode DPPH. Metode DPPH dipilih karena mudah dan praktis digunakan untuk perhitungan penangkapan radikal bebas. DPPH adalah molekul radikal bebas yang dapat berubah warna dari ungu menjadi kuning ketika direaksikan dengan antioksidan. Pada saat DPPH berubah warna antioksidan memberikan satu elektron dan meredam sifat radikal bebas DPPH (Yuhernita \& Juniarti, 2011). Ketika penelitian ini berlangsung, terjadi perubahan warna dari ungu menjadi kuning. Hal tersebut membuktikan bahwa pada ekstrak etanol Paku Laut memiliki aktivitas antioksidan. Kisaran panjang gelombang yang umum digunakan untuk mengukur serapan DPPH adalah 515-517 $\mathrm{nm}$ (Prakash et.al, 2001). Penelitian ini menggunakan panjang gelombang $516 \mathrm{~nm}$ untuk mengukur tingkat serapan DPPH.

Berdasarkan Gambar 2, diketahui bahwa ekstrak spora memiliki aktivitas antioksidan tertinggi dengan nilai $\mathrm{IC}_{50}$ sebesar 23,25 ppm. Sementara itu, IC 50 terendah adalah sampel daun yang diambil sporanya yaitu 125,18 ppm. Menurut Putri dan Hidajati (2015), tingkat kekuatan

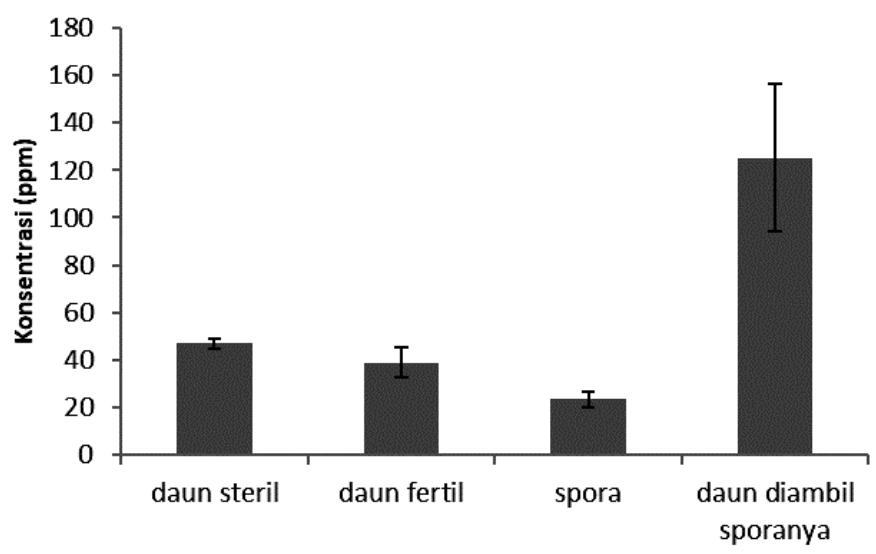

nilai IC50

Gambar 2. Nilai $I C_{50}$ pada sampel daun dan spora Acrostichum aureum L. dengan metode DPPH

antioksidan dibagi menjadi 4 level, yaitu sangat kuat $\left(\mathrm{IC}_{50}<\right.$ 50 ppm), kuat ( $I C_{50} 50-100$ ppm), sedang ( $I C_{50} 100-250$ ppm, dan lemah ( $\mathrm{IC}_{50}$ 250-500 ppm). Oleh karena itu pada sampel spora aktivitas antioksidannya tergolong dalam kategori sangat kuat karena memiliki nilai $\mathrm{IC}_{50}$ kurang dari 50 ppm. Aktivitas antioksidan yang diperoleh dari ekstrak etanolik spora Paku Laut ini lebih tinggi dibandingkan hasil penelitian dari Lai dan Lim (2011), yakni IC 50 pada daun Paku Laut sebesar $540 \pm 0.04 \mathrm{ppm}$ dengan metode yang sama. Pada penelitian Lai dan Lim juga menyebutkan beberapa paku jenis lain seperti Dizplazum esculentum, Pityrogramma calomelanos, dan Pyrossia nunmularifolia memiliki $\mathrm{IC}_{50}$ yang lebih kecil dibandingkan Acrostichum aureum $L$. yaitu sebesar $570 \pm 0.12 \mathrm{ppm}, 1200 \pm 0.18 \mathrm{ppm}, 1470 \pm 0.08 \mathrm{ppm}$. Berdasarkan informasi mengenai beberapa kandungan flavonoid beberapa jenis paku, spora Paku Laut memiliki potensi untuk dikembangkan sebagai bahan alam yang memiliki aktivitas antioksidan yang cukup tinggi. Sehingga perlu dilakukan penelitian lebih lanjut untuk mengetahui potensi dari spora Paku Laut.

\section{Kesimpulan}

Berdasarkan penelitian yang telah dilakukan, diketahui bahwa kandungan fenolik pada daun fertil, daun steril, daun tanpa sopra dan spora daun Paku Laut tidak berbeda secara signifikan. Spora Paku Laut memiliki kandungan flavonoid tertinggi serta memiliki aktivitas antioksidan yang sangat kuat.

\section{Ucapan Terima Kasih}

Ucapan terima kasih khususnya bagi Keluarga Besar Kelompok Studi Kelautan (KSK) Biogama, Fakultas Biologi Universitas Gadjah Mada dan para alumni KSK Biogama. 


\section{Acuan}

Anwar, K., Fadlillaturrahmah, Sari, D.P., 2017, Analisis Kandungan Flavonoid Ekstrak Etanol Daun Binjai (Mangifera caesia Jack.) dan Pengaruhnya terhadap Kadar Glukosa Darah Tikus yang Diinduksi FruktosaLemak Tinggi, Jurnal IImiah Ibnu Sina 2(1), 20-30.

Anwar, K., Rahmanto, B., Triyasmono, L., Rizki, M. I., Halwany, W \& Lestari, F., 2017, The Influence of Leaf Age on Total Phenolic, Flavonoids, and Free Radical Scavenging Capacity of Aquilaria beccariana, Research Journal of Pharmaceutical, Biological and Chemical Sciences, 8(1S), 129-133.

Aziz, T., Febrizky, S., Mario, A.D., 2014, Pengaruh Jenis Pelarut Terhadap Persen YIELD ALKALOID dari Daun Salam India (Murayya koenigii), Teknik Kimia 20(2), 1-6.

Biswal, U.C., Biswal, B., \& Raval M.K., 2003, Chloroplast Biogenesis: From proplastid to gerontplast, The Netherlands, Kluwer Academic Pubisher, Dordrecht.

Chaovanalikit A., Wrolstad, R.E., 2004, Total anthocyanins and total phenolics of fresh and processed cherries and their antioxidant properties, Food Chemistry and Toxicology, 69 (2004), 67-72.

Dia, S.P.S., Nurjanah \& Jacoeb, A.M., 2016, Komposisi Kimia dan Aktivitas Antioksidan Akar, Kulit Batang dan Daun Lindur, JPHPI 2015 18(2), 209.

Firdiyani, F., Agustini, Tri W., \& Ma'ruf, W.F., 2015, Ekstraksi Senyawa Bioaktif sebagai Antioksidan Aami Spirulina platensis Segar dengan Pelarut yang Berbeda. JPHPI 18(1).

Forest Practice Branch Ministry of Forest, 2012, Operational Summary for Vegetation Complex: Fern complex. ISBN 0-7726-4718-6. Province of British Columbia.

Garg, N., Abdel-Aziz, S.M., \& Aeron, A., 2016, Microbes in Food and Health, Springer, Switzerland 42-45.

Hossain, H., jahan, I.A., Nimmi, I., Hossain, Md.A., \& Kawsar, Md.H., 2011. Anti-Inflammatory Activity of The Ethanolic Extract of Acrostichum aureum (Linn.) root, Bangladesh Pharmaeutical Journal 14(2), 107-109

Harborne, J.B., Williams C.A., (2000), Advance in Flavonoid research since 1992, Phytocemistry 55: 481-504.

Ibrahim, M.H., Jaafar, H.Z., 2012, Primary, Secondary Metabolites, $\quad \mathrm{H}_{2} \mathrm{O}_{2}$, Malondialdehyde and Photosynthetic Response of Orthosiphon stimaneus Benth. To Different Irradiance Levels. Molecules 17, 1159-1176
Indrawati, Ni Luh., Razimin., 2013, Bawang Dayak : Si Umbi Ajaib Penakluk Aneka Penyakit. PT AgroMedia Pustaka. Jakarta.

Khan, S.A., Hossain, A., Panthi, S \& Asadujjaman, H.A., 2013, Assesment of antioxidant and Analgesic activity of Acrostichum aureum Linn. (Family Pteridaceae). Pharmacology Online 1, 166-17.

Lai, Y.H., Lim Y.Y., 2011, Evaluation of Antioxcidant Activities of the Methanolic Extract of Selected Ferns in Malaysia. IPCBEE 20.

Li, Q., Kubota, C., 2009, Effect of Suplemental Light Quality on Growth and Phytochemicals of Baby Leaf Lettuce, Exp. Exp. Bot 67,59-64.

Lobo, S.M., G, Khrisnakumar., 2014, Studies on Ecological Anatomy of The Mangrove Fern Acrostichum Aureum L., International Journal of Plant, Animal and Environtment Sciences 4(1), 195-200.

Molyneux, P., 2003, The Use of The Stable Free Radical Diphenylpicrilhydrazyl (DPPH) for Estimating Antioxidant Activity. J.Sci. Technol 26(2), 211-219.

Neldawati, Ratnawulan, \& Gusnedi, 2013, Analisis Nilai Absorbansi dalam Penentuan Kadar Flavonoid untuk Berbagai Jenis Daun Tanaman Obat, Pillar of Physics 2, 76-83.

Prakash, A., 2001, Antioxidant Activity, Medallion Laboratories analytical progress 19 (2), 1-6.

Pekal, A., Pyrzynska, K., 2014, Evaluation of Aluminium Complexation Reaction for Flavonoid Content Assay, Food Anal. Methods (2014) 7, 1776-1728.

Putri, A.S.P., Hidajati, N., 2015, Uji aktivitas antioksidan senyawa fenolik ekstrak methanol kulit batang tumbuhan Nyiri batu (Xylocarpus moluccencis), Unesa Journal of chemistry 4(1), 37-42.

Ragavan, P., Saxena, A., Mohan, P.M., \& Ravinchandran, K., 2014, A Hybrid of Acrostichum from Andaman and Nicobar Island India, ISME/GLOMIS Electronic Journal 12(3), 9-13.

Raja, S., Ravindranadh, K., 2014, A Complete Profile on Acrostichum Aureum : Traditional Uses, Pharmacological activities and Phytoconstituens, World Journal of Pharmaceutical Research 3(10), 624 $-630$

Raja, S. Ravindranadh, K., 2014, Preliminary phytochemical screening of different solvent extracts of whole plants of Acrostichum aureum, World Journal of Pharmaceutical Sciences, 2(12), 1753-1759. 
Rhodes, M.J.C., Yemm, E.W., 1965, The metabolism of Nucleic Acids and Proteins in young leaves of Barley. Biochim, biophys.Acta. (In Press).

Sarastani, D., Soekarto S.T., Muhchtadi T.R., Fardiaz, D \& Apriyantono, A., 2002, Aktivitas antioksidan ekstrak dan fraksi ekstrak Biji Atung (Parinarium glaberrimum Hassk.). Jurnal Teknologi dan Industri Pangan 13(2), 149-156.

Shebis, Y., ILuz, D., Tahan, Y.K., Dubinsky, Z \& Yehoshua, Y., 2013. Natural Antioxidant : Function and Sources. Food and Nutrition Sciences 4, 634-649
Ukoha, P.O., Cemaluk, E.A.C., Nnamdi, O.L \& Madus, E.P., 2011, Tannins and other phytochemical of the Samanaea saman pods and their antimicrobial activities. African Journal of Pure and Applied Chemistry 5(8), 237-244.

Yuhernita., Juniarti., 2011, Analisis senyawa Metabolit Sekunder dari Ekstrak Metanol Daun Surian yang Berpotensi sebagai Antioksidan, Makara Sains, 15 (1), 48-52 